\title{
Mineral constituents of roasted cashew nuts (Anacardium occidentale $L$.) from Southeastern Nigeria
}

\author{
Nnorom C. Innocent, Ewuzie Ugochukwu \\ Environmental Chemistry Unit, Department of Pure and Industrial Chemistry, Abia State University, Uturu, \\ Nigeria.
}

\begin{abstract}
This paper presents the results of the determination of $\mathrm{Ca}, \mathrm{Cr}, \mathrm{Cu}, \mathrm{Fe}, \mathrm{K}, \mathrm{Mg}, \mathrm{Mn}, \mathrm{Na}, \mathrm{Ni}$, and $\mathrm{Zn}$ in 30 samples of roasted cashew nuts from six towns in Southeastern Nigeria. The elements were determined by flame atomic absorption spectroscopy with background correction after ashing of the nuts at $450{ }^{\circ} \mathrm{C}$ and mineralizing with acids. The results ( $\mathrm{mg} / \mathrm{kg}$; dry matter) showed that $K$ (overall mean) occurred at $6200 \pm 130$,

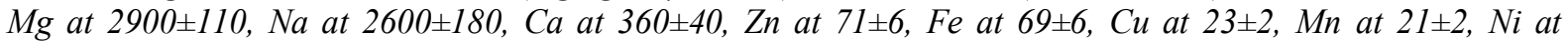
$0.25 \pm 0.07$ and $\mathrm{Cr}$ at $0.078 \pm 0.036$. Consumption of cashew nuts in the two retail weights of approximately 35 and $79 \mathrm{~g}$ will provide (mg/day): 217-489 $\mathrm{K}, 102-229 \mathrm{Mg}$, 91-205 Na, 13-28 Ca, 2.5-5.6 Zn, 2.4-5.5 Fe, 0.8$1.8 \mathrm{Cu}$ and 0.7-1.7 Mn. Compared to the Reference Daily Intake, these values will amount (\%) to 40-90 for Cu, 35-85 for Mn and 13-31 for Fe. PCA analysis revealed interrelationships among the metals and suggested that the metals were of natural sources. Roasted cashew nuts would therefore serve as a dietary source of essential elements and pose no toxicological health risks.
\end{abstract}

Keywords: Foods, micronutrients, Nigeria, roasted cashew nut, trace elements

\section{Introduction}

The cashew tree, Anacardium occidentale L., belongs to the Anacardiaceae family and is a versatile tree nut $[1,2]$ that is native to Brazil. The "cashew fruit" comprises the cashew "apple", a pseudo-fruit formed by an enlarged peduncle, and the true fruit, a kidney-shaped (reniform) achene about $3 \mathrm{~cm}$ long with a hard grey-green pericarp [3, 4]. This plant nowadays is cultivated in tropical regions worldwide. Cashew was introduced in Nigeria in the 15th/16th century by the Portuguese explorers $[5,6]$ and it was mainly used in afforestation schemes for the control of erosion in the former Eastern Nigeria. Commercial cashew plantations started in Nigeria in the early 1950s with the establishment of first commercial plantations [7]. Presently, Nigeria ranks among the largest producers of cashew nuts together with India with 650,000 and 613,000 metric tons, respectively, and other major producers are Côte d'Ivoire, Vietnam, Indonesia, Philippines, Brazil, GuineaBissau, Tanzania and Benin with total output of 2, 757, 598 metric tons in 2010 [8]. The average yield of nuts of a mature tree is in the range of 7 to $11 \mathrm{~kg}$ per annum. Although the cashew tree is capable of living for 50 to 60 years, most trees produce nuts for about 15 to 20 years [2].

Around the world, and in Nigeria in particular, the name "Cashew' refers to both the "apple" and the kidney-shaped, nutlike seed of the cashew tree. The cashew apple is well consumed during the season while the nut is roasted and consumed in large quantities in Nigeria all year round. Cashew nuts are roasted over open fires or in red hot charcoal in most Nigerian rural communities, allowed to cool before they are cracked and consumed. Currently, 75 to $80 \%$ of cashew nuts produced in Nigeria are exported, as only very few companies are involved in local processing of the produce [7,9].

Data on the elemental composition of food and feedstuff are of great importance because of their benefits (nutritional value) as well as risk (estimation of toxic exposure) [10, 11, 12]. Metallic elements including $\mathrm{Zn}, \mathrm{Fe}, \mathrm{Mg}, \mathrm{Mn}$, Co and $\mathrm{Cr}$ (III) play important roles in different human metabolism and are therefore nutrient elements for human health while $\mathrm{Pb}, \mathrm{Cd}$ and $\mathrm{Hg}$ and $\mathrm{Cr}$ (VI) are known to be toxic to human $[13,14]$.

Several studies have shown nuts to be a rich source of nutrients, mainly protein, fat, vitamins, as well as minerals such as $\mathrm{P}, \mathrm{K}, \mathrm{Mg}, \mathrm{Fe}[15,16]$. Consequently nuts have been recognized as important sources of some essential elements (e.g. B, Se, $\mathrm{Cu}, \mathrm{Zn}, \mathrm{Fe}$ and $\mathrm{Mn}$ ) in human nutrition $[10,17]$. Considering the high production and consumption rates and the importance of understanding the mineral composition of roasted cashew nuts consumed in Nigeria, this present paper reports the results of validated instrumental determination of the mineral composition of roasted cashew nuts. The outcome of this research provides information on the micronutrient contents of roasted cashew nuts and adds to the existing database of element composition of foods and foodstuff in Nigeria. 


\subsection{Sampling}

\section{Materials and method}

Roasted cashew nuts are considered important snack in Nigeria. They are marketed in wraps of $\$ 50$ or \$100 (\$1= 156). Cashew nuts from six different towns in Abia State, Southeastern Nigeria (namely: Ubakala, Omoba, Ntigha, Uturu, Uzuakoli and Obehie) were sampled and studied. For each of the six towns, three wraps were purchased at five different locations and pooled together to give five composite samples per town. A total of thirty (30) samples were packed in brand new sealable polyethylene bags and taken to the laboratory. The cashew nuts were purchased as products, processed (roasted), packaged and on sale from hawkers and vendors in motor loading bays, streets, institutions or road sides.

\subsection{Elemental analysis}

In the laboratory, the samples were crushed in porcelain mortar, homogenized, and dried to constant weight at $105^{\circ} \mathrm{C}$ in an oven for $6 \mathrm{~h}$, and allowed to cool. It was then sifted through $2 \mathrm{~mm}$ sieve. $1 \mathrm{~g}$ of sample was ashed in a muffle furnace at an oven temperature of $450{ }^{\circ} \mathrm{C}$ for $5 \mathrm{~h}$ and quantitatively transferred into a 250 $\mathrm{ml}$ conical flask. Next, $10 \mathrm{ml}$ of the digestion acid mixture (ratio 1:2:2 of perchloric, nitric and sulphuric acids) was added into the ash and gently heated on a hot plate in a fume hood until a white fume was observed which signified that digestion was complete. The digest was allowed to cool and $20 \mathrm{ml}$ of distilled water was added to bring the minerals into solution and subsequently filtered using ashless Whatman filter paper into a $100 \mathrm{ml}$ calibrated volumetric flask and made up to mark with distilled water. The digests were analyzed for $\mathrm{Ca}, \mathrm{Cr}, \mathrm{Cu}$, Fe, K, Mg, Mn, Na, Ni, and Zn using Buck 200A (Buck Scientific; Norwalk, CT, USA) flame atomic absorption spectrometer with background correction.

The elements, $\mathrm{Ba}, \mathrm{Pb}, \mathrm{Cd}$ and $\mathrm{V}$ were also determined and were found to be below the detection limits of $0.001 \mathrm{mg} / \mathrm{kg}$ dry matter $(\mathrm{dm})$. This observation for $\mathrm{Ba}, \mathrm{Pb}, \mathrm{Cd}$ and $\mathrm{V}$ compares well with results reported in literature for cashew nuts $(0.0005 \mathrm{mg} / \mathrm{kg}$ for $\mathrm{Cd} ; 0.002-0.3 \mathrm{mg} / \mathrm{kg}$ for $\mathrm{Pb}$ and $0.001 \mathrm{mg} / \mathrm{kg}$ for $\mathrm{V})$ by Preedy et al. [18]. Hence the results for these elements were not presented

\subsection{Quality assurance}

Appropriate quality assurance procedures and precautions were carried out to ensure the reliability of the results. All chemicals used were of analytical grade: $\mathrm{H}_{2} \mathrm{SO}_{4}(98 \%, \mathrm{BDH}$ Laboratory Supplies, Poole, England); $\mathrm{HNO}_{3}$ (69\%, BDH Laboratory Supplies, Poole, England); $\mathrm{HClO}_{4}$ (70\%, Sigma-Aldrich, St. Louis, USA). To eliminate the risk of contamination during the experiments, all plastic and glassware were carefully cleaned by washing, rinsing severally with tap water, and then soaking in $5 \% \mathrm{HNO}_{3}$ solution for a minimum of $24 \mathrm{~h}$. They were rinsed severally with deionized water before use. Reagent blank determinations were used to correct the instrument readings. The accuracy of the analytical method was calculated by analyzing a certified reference material (CRM: Accu Standards, New Haven Connecticut, USA). Also spike recovery was conducted on some of the samples. Detection limit is defined as the concentration corresponding to three times the standard deviation of seven blanks. Recoveries for the CRM varied from 96-102\% and for the spiking study, from 97101\% (Tables 1 and 2 respectively).

Table 1. Elements concentration in certified reference materials (Accu standards USA)

\begin{tabular}{lccc}
\hline Element & Certified value $(\mathrm{mg} / \mathrm{L})$ & Our value $(\mathrm{mg} / \mathrm{L})^{\mathrm{D}}$ & Recovery $(\%)$ \\
\hline $\mathrm{Ca}$ & $3.0 \pm 0.2$ & $2.89 \pm 0.16^{\mathrm{a}}$ & 96 \\
$\mathrm{Cd}$ & $0.375 \pm 0.167$ & $0.372 \pm 0.124$ & 99 \\
$\mathrm{Cu}$ & $0.75 \pm 0.35$ & $0.734 \pm 0.332$ & 98 \\
$\mathrm{~K}$ & $12.5 \pm 3.53$ & $12.24 \pm 3.31$ & 98 \\
$\mathrm{Na}$ & $7.5 \pm 3.5$ & $7.56 \pm 3.51$ & 101 \\
$\mathrm{~Pb}$ & $0.375 \pm 0.177$ & $0.384 \pm 0.174$ & 102 \\
$\mathrm{Zn}$ & $0.88 \pm 0.24$ & $0.89 \pm 0.32$ & 101 \\
\hline
\end{tabular}

Table 2. Spiked recovery of some of the metals $(n=3)$

\begin{tabular}{llll}
\hline Elements & $\begin{array}{l}\text { Spiked } \\
\text { concentration }(\mathrm{mg} / \mathrm{kg})\end{array}$ & $\begin{array}{l}\text { Recovered } \\
\text { concentration }(\mathrm{mg} / \mathrm{kg})\end{array}$ & Recovery $(\%)$ \\
\hline $\mathrm{Fe}$ & $23.45 \pm 0.06^{\mathrm{a}}$ & $25.98 \pm 1.52$ & 98 \\
$\mathrm{Cu}$ & $20.78 \pm 0.17$ & $20.56 \pm 0.41$ & 99 \\
$\mathrm{Zn}$ & $66.3 \pm 0.1$ & $64.2 \pm 1.9$ & 97 \\
$\mathrm{~K}$ & $5770 \pm 1$ & $5668 \pm 7$ & 98 \\
$\mathrm{Na}$ & $2902 \pm 8$ & $2920 \pm 3$ & 101 \\
$\mathrm{Mg}$ & $2558 \pm 1$ & $2580 \pm 2$ & 101 \\
\hline
\end{tabular}

aean \pm standard deviation 


\subsection{Statistical analysis}

Statistical analysis of data was carried out using SPSS 16.0 for windows (SPSS Inc., Polar Engineering and Consulting 2007) and Excel 2007 statistical package programs. One-way ANOVA was employed to find the significant differences of metallic elements (or trace metal) concentrations in cashew nuts with respect to sampling areas. The significance was set at $p<0.05$. Also, two-tailed correlation analyses of metallic constituents of the samples analyzed, depending on sites were conducted. Principal component analysis (PCA) used in this study was aimed at visualizing the principal attributes of the analytical data and distribution of elements' concentrations in cashew nuts, which will be difficult to identify with tables alone. It generates a new set of values of linearly uncorrelated variables called the principal components (PCs) through linear transformation of a set of observations of perhaps correlated variables. The aim of Varimax normalized rotation is to maximize the variances of normalized factor loadings across variables for each factor [19].

\subsection{Estimation of metals intake}

In the regions studied, roasted cashew nuts are marketed in two different prices to meet the needs of various income earners: $\$ 100$ (average weight of $79.005 \pm 0.090 \mathrm{~g}$ ) and $\$ 50$ (average weight of $35.011 \pm 0.028$ $\mathrm{g}$ ). Survey conducted indicated that, on the average, an individual consumes a minimum of $\$ 50$ and a maximum of 100 worth of roasted cashew nuts daily. Therefore, the daily intakes of $\mathrm{Ca}, \mathrm{Cr}, \mathrm{Cu}, \mathrm{Fe}, \mathrm{K}, \mathrm{Mg}, \mathrm{Mn}, \mathrm{Na}, \mathrm{Ni}$, and $\mathrm{Zn}$ from cashew nuts were estimated based on this range (consumption of $35-75 \mathrm{~g}$ ) using the mean results of this study. The metals intake was compared with Reference Daily Intakes (RDI) for metals recommended by the FDA [20], FAO/WHO [21], USDA [22] and the Institute of Medicine [23].

\subsection{Elemental composition of cashew nuts}

\section{Results and discussion}

The mean results (mg/kg dry weight) for $\mathrm{Ca}, \mathrm{Cr}, \mathrm{Cu}, \mathrm{Fe}, \mathrm{K}, \mathrm{Mg}, \mathrm{Mn}, \mathrm{Na}, \mathrm{Ni}$, and $\mathrm{Zn}$ contents of cashew nuts and the combined data for all sampling areas were presented in Table 3. Among the major elements examined, the element $\mathrm{K}$ was the most abundant with overall mean concentration of $6200 \pm 130 \mathrm{mg} / \mathrm{kg}$ (range $5400-7100)$ and this was comparable with the available data of $6600 \pm 20 \mathrm{mg} / \mathrm{kg} \mathrm{dm}$ and $7301 \pm 396 \mathrm{mg} / \mathrm{kg} \mathrm{dm}$ reported by Preedy et al. [18] and Naozuka et al. [24] respectively. Potassium serves an electrolyte for maintaining normal fluid balance in cells and a delicate balance of this element is reported to prevent an increase in blood pressure and maintain normal cardiac rhythm [25]. Thus cashew nuts can serve as a good source of this essential nutrient.

The overall mean calcium content was $360 \pm 40 \mathrm{mg} / \mathrm{kg}$, which ranged between $310 \pm 40 \mathrm{mg} / \mathrm{kg}$ for Obehie and $420 \pm 10 \mathrm{mg} / \mathrm{kg}$ for Uturu (Table 3). These values were higher than the overall mean of $242 \pm 30$ $\mathrm{mg} / \mathrm{kg} \mathrm{dm}$ shown in the study by Naozuka et al. [22]. Calcium ion is known to be involved in and regulates the permeability and electrical properties of biological membranes. It plays essential roles in neuromuscular function, in many enzyme-mediated processes, blood clotting, and in providing rigidity to the skeleton via phosphate salts [26]. Its non-structural roles require the strict maintenance of ionized calcium concentration in tissue fluids at the expense of the skeleton if necessary, and it is therefore the skeleton which is at risk if the supply of Ca falls short of requirement [21].

The minimum and maximum $\mathrm{Na}$ contents of samples from this study were 2300 and $3000 \mathrm{mg} / \mathrm{kg} \mathrm{dm}$ respectively. These $\mathrm{Na}$ concentrations were between $21-27$ times the mean $\mathrm{Na}$ content reported in literature $(110 \pm 30 \mathrm{mg} / \mathrm{kg} \mathrm{dm})$ by Preedy et al. [18]. The amount of $\mathrm{Na}$ in a diet markedly affects the health and nutrition of the individual. Although $\mathrm{Na}$ is necessary to maintain balance in physical fluid systems and is also required for the operation of nerves and muscles, high-sodium diets are linked to a number of health problems including damage of the kidneys and increase in the possibilities of hypertension [26]. Methods of preparation of the nuts prior to the roasting processes could contribute to the high Na content of the investigated samples. For instance, the nuts are usually salted using common salt to meet the organoleptic requirements and acceptability of consumers.

Mean Mg content of cashew nuts in this study $(2900 \pm 110 \mathrm{mg} / \mathrm{kg})$ compared well with data available in literature. For instance, Naozuka et al. [24] and Preedy et al. [18] report mean Mg concentrations of 2794 \pm 267 and $2800 \pm 5 \mathrm{mg} / \mathrm{kg} \mathrm{dm}$ respectively for cashew nuts. However, these values are lower than the mean value of $4100 \pm 100 \mathrm{mg} / \mathrm{kg} \mathrm{dm}$ reported for Brazil nuts [18]. The importance of $\mathrm{Mg}$ has not only been depicted in its function in the skeleton, but also in muscles and soft tissues, such as a co-factor of many enzymes involved in energy metabolism, protein synthesis, RNA and DNA synthesis, and maintenance of the electrical potential of nerve tissues and cell membranes [26]. The element's dietary deficiency, which is sufficient to induce pathologic changes, is however rare [21].

Nickel toxicity at elevated levels is more prominent, but trace amounts may be beneficial as an activator of some enzyme systems [27, 28]; although its essential roles have not been totally proved in humans. 
The mean Ni content of cashew nuts in this study was $0.25 \pm 0.07 \mathrm{mg} / \mathrm{kg} \mathrm{dm}$ which is well below the values reported by Preedy et al. [18] for cashew nuts ( $3 \mathrm{mg} / \mathrm{kg} \mathrm{dm})$ and Brazil nuts $(7 \pm 30 \mathrm{mg} / \mathrm{kg} \mathrm{dm})$.

The element $\mathrm{Cr}$ was not detected in cashews sampled from Omoba and Ntigha. Nevertheless, the overall range was from $<0.001$ to $0.14 \mathrm{mg} / \mathrm{kg} \mathrm{dm}$ (Table 3). Reports indicate that $\mathrm{Cr}$ (III) is an essential element that helps the body use sugar, protein, and fat, while at the same time it (especially, Cr VI) is carcinogenic for organisms [29]. The low level of total $\mathrm{Cr}$ in cashew nuts from this study when compared with those reported by Preedy et al. [18] for cashew nut $(0.01-0.3 \mathrm{mg} / \mathrm{kg})$ and Brazil nuts $(0.02-0.8 \mathrm{mg} / \mathrm{kg})$ does not indicate health concern.

The overall mean $\mathrm{Cu}$ concentration of the present study $(23 \pm 2 \mathrm{mg} / \mathrm{kg})$ agreed with the reported values of 20, $19.1 \pm 0.1$ and $21 \pm 20 \mathrm{mg} / \mathrm{kg} \mathrm{dm}$ by Rodushkin et al. [15]; Nascimento et al. [17] and Preedy et al. [18] respectively, but is greater than the value of $6.1 \pm 0.5 \mathrm{mg} / \mathrm{kg} \mathrm{dm}$ reported by Naozuka et al. [24]. Copper is essential for good health but very high intakes can cause adverse health problems such as liver and kidney damage [30]. Copper deficiency leads to hypochromic anemia, leucopenia and osteoporosis in children [31]. Roasted cashew nuts are therefore a good source of $\mathrm{Cu}$ to consumers of this tasty delicacy.

The significance of $\mathrm{Fe}$ in maintaining good health and well being has long been acknowledged by nutritionists. The mean $\mathrm{Fe}$ concentration of this study was $69 \pm 6 \mathrm{mg} / \mathrm{kg} \mathrm{dm}$ and this was close to the values reported in the literature which ranged from 53.3 to $67 \mathrm{mg} / \mathrm{kg} \mathrm{dm}$ for cashew nuts $[15,17,18,24]$ and from 22 to $37 \mathrm{mg} / \mathrm{kg}$ for Brazil nuts $[15,18]$. It is recognized that adequate iron in a diet is very imperative for diminishing the incidence of anemia [32]. Fe deficiencies are often associated with anemia and, thus, diminish working capacity and impaired intellectual development [33].

The overall mean of Mn was $21 \pm 2$ (range: $17-24) \mathrm{mg} / \mathrm{kg} \mathrm{dm}$ (Table 3). Preedy et al. [18] reports a similar average content of $23 \pm 30 \mathrm{mg} / \mathrm{kg} \mathrm{dm}$, while a lower mean of $13 \pm 1 \mathrm{mg} / \mathrm{kg} \mathrm{dm}$, is reported in a study by Naozuka et al. [24]. The deficiency of Mn can produce severe skeletal and reproductive abnormalities in mammals, while high doses of Mn could produce adverse effects primarily on the lungs and on the brain [28]. Manganese plays a vital role in the control of diabetes [25], thus cashew nut will be a good source of Mn to cushion these abnormalities.

The results of $\mathrm{Zn}$ in roasted cashew nuts ranged between 58 and $81 \mathrm{mg} / \mathrm{kg}$ while the median is 59 . The overall mean $\mathrm{Zn}$ concentration of this study $(71 \pm 6 \mathrm{mg} / \mathrm{kg})$ is higher than the values of $(57 \pm 10 \mathrm{mg} / \mathrm{kg})$ and $(54 \pm 7$ $\mathrm{mg} / \mathrm{kg}$ ) reported by Preedy et al. [18] and Naozuka et al. [24] respectively. Zn plays essential role as metalloenzymes and as a cofactor of large number of enzymes [20].

\subsection{Relationship between metals studied}

The result of one-way ANOVA showed that sampling areas significantly influenced the mean levels of metals in cashew nuts. The results of the correlation analyses are presented in Tables $1 \mathrm{~S}, 2 \mathrm{~S}$ and $3 \mathrm{~S}$ (supporting tables). In Ubakala, minimum and maximum significant positive correlation existed for $\mathrm{Mn}-\mathrm{Ca}(\mathrm{r}=0.982)$ and $\mathrm{Cu}-\mathrm{K}(\mathrm{r}=0.996)$ respectively at $p=0.01$, and in $\mathrm{Zn}-\mathrm{Ca}(\mathrm{r}=0.881)$ and $\mathrm{Zn}-\mathrm{Na}(\mathrm{r}=0.956)$ respectively at $p=0.05$. Samples from Omoba only showed significant positive correlations in $\mathrm{Ca}-\mathrm{Mg}(\mathrm{r}=0.923), \mathrm{Ca}-\mathrm{Ni}(\mathrm{r}=0.938)$, Na$\mathrm{Ni}(\mathrm{r}=0.946), \mathrm{Na}-\mathrm{Mg}(\mathrm{r}=0.986)$ and $\mathrm{Mg}-\mathrm{Ni}(\mathrm{r}=0.964)$. For cashew nuts from Ntigha, minimum significant positive correlation was found in $\mathrm{Mg}-\mathrm{Na}(\mathrm{r}=0.887)$ and $\mathrm{Fe}-\mathrm{K}(\mathrm{r}=0.959)$ at 0.05 and 0.01 levels respectively, while maximum significant positive correlation exists in $\mathrm{Ni}-\mathrm{Ca} \& \mathrm{Cu}-\mathrm{Na}(\mathrm{r}=0.951)$ and $\mathrm{Zn}-\mathrm{Fe}(\mathrm{r}=0.998)$ at 0.05 and 0.01 levels respectively. For products from Uturu, Mg-Zn $(r=0.891)$ and $\mathrm{Na}-\mathrm{Fe}(\mathrm{r}=0.944)$ had the minimum significant positive correlation at 0.05 and 0.01 levels respectively, while maximum significant positive correlation was found in $\mathrm{Ca}-\mathrm{K}(\mathrm{r}=0.963)$ and $\mathrm{Fe}-\mathrm{K}(\mathrm{r}=0.992)$ at 0.05 and 0.01 levels respectively. Amongst the metals in samples from Uzuakoli, the minimum positive correlation of $\mathrm{Na}-\mathrm{Ca}(\mathrm{r}=0.890)$ and $\mathrm{Mn}-$ $\mathrm{Cu}(\mathrm{r}=0.963)$ was significant at 0.05 and 0.01 levels respectively, while $\mathrm{Mg}-\mathrm{Ca} \& \mathrm{Zn}-\mathrm{Fe}(\mathrm{r}=0.958)$ and $\mathrm{Fe}-\mathrm{Ni}$ $(\mathrm{r}=0.992)$ showed maximum positive correlations that were significant at 0.05 and 0.01 levels respectively. In Obehie, it was discovered that the minimum and maximum significant positive correlation at 0.05 level exist in $\mathrm{Na}-\mathrm{Fe}(\mathrm{r}=0.880)$ and $\mathrm{Mg}-\mathrm{Fe}(\mathrm{r}=0.956)$ respectively, while the minimum and maximum significant positive correlation at 0.01 level was found in $\mathrm{Ca}-\mathrm{Mn}(\mathrm{r}=0.958)$ and $\mathrm{Fe}-\mathrm{Mn}(\mathrm{r}=0.995)$ respectively. 
Table 3. Elements content of cashew nut from areas in Southeastern Nigeria $(\mathrm{mg} / \mathrm{kg}$; Mean $(\mathrm{n}=5), \mathrm{SD}$, Range and Median)

\begin{tabular}{|c|c|c|c|c|c|c|c|}
\hline Element & Uturu & Uzoakoli & Obehie & Ubakala & Omoba & Ntigha & Combined $(n=30)$ \\
\hline \multirow[t]{3}{*}{$\overline{\mathrm{Ca}}$} & $420 \pm 10$ & $360 \pm 40$ & $310 \pm 20$ & $370 \pm 10$ & $330 \pm 20$ & $390 \pm 10$ & $360 \pm 40$ \\
\hline & $400-430$ & $310-400$ & $290-330$ & $350-380$ & $300-350$ & $380-410$ & $290-430$ \\
\hline & 420 & 360 & 300 & 370 & 330 & 390 & 380 \\
\hline \multirow[t]{3}{*}{$\mathrm{Cr}$} & $0.06 \pm 0.03$ & $0.09 \pm 0.03$ & $0.11 \pm 0.03$ & $0.043 \pm 0.021$ & ND & ND & $0.078 \pm 0.036$ \\
\hline & $<0.001-0.08$ & $<0.001-0.12$ & $<0.001-0.14$ & $<0.001-0.060$ & - & - & $<0.001-0.14$ \\
\hline & 0.03 & 0.06 & 0.09 & 0.02 & - & - & - \\
\hline \multirow[t]{3}{*}{$\mathrm{Cu}$} & $25 \pm 1$ & $22 \pm 1$ & $23 \pm 1$ & $23 \pm 2$ & $22 \pm 2$ & $23 \pm 2$ & $23 \pm 2$ \\
\hline & $23-26$ & $21-24$ & $21-24$ & $21-24$ & $21-25$ & $21-25$ & $21-26$ \\
\hline & 25 & 22 & 23 & 23 & 22 & 22 & 23 \\
\hline \multirow[t]{3}{*}{$\mathrm{Fe}$} & $69 \pm 3$ & $62 \pm 3$ & $62 \pm 2$ & $70 \pm 3$ & $75 \pm 3$ & $74 \pm 3$ & $69 \pm 6$ \\
\hline & $66-72$ & $59-67$ & $60-65$ & $66-74$ & $71-79$ & $70-78$ & $59-79$ \\
\hline & 70 & 62 & 63 & 69 & 75 & 74 & 70 \\
\hline \multirow[t]{3}{*}{$\mathrm{K}$} & $7000 \pm 90$ & $6100 \pm 260$ & $6200 \pm 300$ & $6100 \pm 140$ & $5800 \pm 230$ & $6100 \pm 100$ & $6200 \pm 130$ \\
\hline & $6900-7100$ & $5900-6600$ & $5900-6700$ & $5900-6200$ & $5400-6000$ & $6000-6200$ & $5400-7100$ \\
\hline & 7000 & 6000 & 6000 & 6000 & 5900 & 6100 & 6100 \\
\hline \multirow[t]{3}{*}{$\mathrm{Mg}$} & $2900 \pm 140$ & $2700 \pm 60$ & $2900 \pm 50$ & $2900 \pm 40$ & $2900 \pm 100$ & $2900 \pm 130$ & $2900 \pm 110$ \\
\hline & $2700-3100$ & $2700-2800$ & $2900-3000$ & $2800-2900$ & $2700-3000$ & $2700-3000$ & $2700-3100$ \\
\hline & 2900 & 2700 & 2900 & 2900 & 2900 & 3000 & 2900 \\
\hline \multirow[t]{3}{*}{$\mathrm{Mn}$} & $22 \pm 2$ & $21 \pm 1$ & $21 \pm 1$ & $18 \pm 1$ & $20 \pm 1$ & $22 \pm 1$ & $21 \pm 2$ \\
\hline & $20-24$ & $19-77$ & $20-22$ & $17-19$ & $19-22$ & $20-22$ & $17-24$ \\
\hline & 22 & 21 & 22 & 18 & 21 & 22 & 21 \\
\hline \multirow[t]{3}{*}{$\mathrm{Na}$} & $2500 \pm 70$ & $2400 \pm 60$ & $2600 \pm 150$ & $2500 \pm 70$ & $2500 \pm 100$ & $2900 \pm 110$ & $2600 \pm 180$ \\
\hline & $2500-2600$ & $2300-2500$ & $2500-2900$ & $2400-2600$ & $2500-2700$ & $2800-3000$ & $2300-3000$ \\
\hline & 2500 & 2400 & 2600 & 2500 & 2500 & 2900 & 2500 \\
\hline \multirow[t]{3}{*}{$\mathrm{Ni}$} & $0.28 \pm 0.04$ & $0.22 \pm 0.04$ & $0.18 \pm 0.04$ & $0.36 \pm 0.07$ & $0.27 \pm 0.03$ & $0.21 \pm 0.03$ & $0.25 \pm 0.07$ \\
\hline & $0.24-0.35$ & $0.17-0.28$ & $0.15-0.24$ & $0.25-0.44$ & $0.24-0.31$ & $0.18-0.25$ & $0.15-0.44$ \\
\hline & 0.28 & 0.21 & 0.18 & 0.35 & 0.26 & 0.21 & 0.25 \\
\hline \multirow[t]{3}{*}{$\mathrm{Zn}$} & $67 \pm 3$ & $72 \pm 4$ & $61 \pm 3$ & $75 \pm 4$ & $70 \pm 3$ & $77 \pm 4$ & $71 \pm 6$ \\
\hline & $62-70$ & $69-77$ & $58-65$ & $69-80$ & $66-75$ & $73-81$ & $58-81$ \\
\hline & 69 & 70 & 60 & 76 & 70 & 78 & 59 \\
\hline
\end{tabular}

ND : Not detected; detection limit $=0.001 \mathrm{mg} / \mathrm{kg}$

\subsection{Estimation of micro-nutrient intake}

The consumption of 35-79 $\mathrm{g}$ of roasted cashew nut daily will furnish the body with 217-489 mg of K; 91-205 mg of $\mathrm{Na}$ and 13-28 mg of Ca daily. The recommended daily intake for $\mathrm{Ca}$ is $800 \mathrm{mg}$ [21], thus daily consumption of cashew nuts supplies the human body with essential $\mathrm{Ca}$ at $<5 \%$ of adequate intake. The amount of $\mathrm{Na}$ a consumer derives on eating $35-79 \mathrm{~g}$ of cashew nuts is adequate and is in no way likely to pose risk of hypertension. The recommended minimum dietary allowance for $\mathrm{Na}$ is $1500 \mathrm{mg} / \mathrm{day}$ and maximum of $2400 \mathrm{mg}$ daily [22,34]. Thus it will take the consumption of about $923 \mathrm{~g}$ (26 wraps of $\$ 50$ or 12 wraps of $\$ 100$ worth) of roasted cashew nuts to exceed the maximum limit, which is about 11.6 times the calculated quantity consumed daily. Similarly, consumers should not be concerned over potassium toxicity from consumption of roasted cashew nuts, because the intake value is far below the recommended dietary allowance of $4700 \mathrm{mg} / \mathrm{day}$ [21].

The Food and Nutrition Board [35] recommends dietary Mg allowance of $300 \mathrm{mg} / \mathrm{day}$ for women and $350 \mathrm{mg} /$ day for men. The intake of Mg on consumption of 35-79 g cashew nuts is between 102 and $229 \mathrm{mg}$ daily, thus it will take the consumption of about 103 to $120 \mathrm{~g}$ of cashew nuts daily to exceed these limits.

Daily reference values of 2 and $18 \mathrm{mg}$ for $\mathrm{Cu}$ and Fe respectively were set by FDA [20]. The daily consumption of 35-79 $\mathrm{g}$ of cashew nuts will supply the body with $0.8-1.8 \mathrm{mg}$ and $2.4-5.5 \mathrm{mg}$ of $\mathrm{Cu}$ and $\mathrm{Fe}$ daily respectively. For $\mathrm{Cu}$, this will amount to $40-90 \%$ of the daily reference value, and for $\mathrm{Fe}$ it will amount to $13-31 \%$ of the daily reference value. Thus cashew nuts are good sources of $\mathrm{Cu}$ and Fe; it will only take the daily consumption of $87 \mathrm{~g}$ and $261 \mathrm{~g}$ of cashew nuts to exceed the daily reference values of $\mathrm{Cu}$ and Fe respectively. For $\mathrm{Zn}$, this consumption will provide the body with $2.5-5.6 \mathrm{mg}$ of element daily, while the FDA recommends a daily reference value of $15 \mathrm{mg}$ for $\mathrm{Zn}$. The levels of $\mathrm{Zn}$ derived from the consumption of cashew nuts per day are about $17-37 \%$ of the reference value. $\mathrm{Zn}$ exerts anti-diarrhea activity and regulates fertility; hence the consumption of cashew nuts is recommended for both men and women without any attendant health risk.

The Institute of Medicine [23] recommends an RDI of $0.5 \mathrm{mg}$ for $\mathrm{Ni}$; while Food and Drug Administration [20] recommends $2 \mathrm{mg}$ as a RDI for Mn. The consumption of 35-79 $\mathrm{g}$ of cashew nuts will supply $0.009-0.02 \mathrm{mg}$ of $\mathrm{Ni}$ and $0.7-1.7 \mathrm{mg}$ of $\mathrm{Mn}$. For $\mathrm{Ni}$, this will amount to $1.8-4 \%$ of the RDI, and for $\mathrm{Mn}$, it will amount to $35-85 \%$ of the RDI. Studies by Nascimento et al. [17] showed that it is possible to assume that 75 of $\mathrm{Cu}$ and $70 \%$ of $\mathrm{Fe}$ present in cashew nut could be bioavailable. This buttresses the value of cashew nuts as a good source of these elements in human diet.

Earlier, studies have shown that the cashew nut contains $47 \%$ fat, $21 \%$ protein and $22 \%$ carbohydrate as well as vitamins, especially thiamine $[5,36]$. Similarly, the protein content of cashew nut has been show to be complete, having all the essential amino acids. Cashew nuts also provide more energy compared to other foods. For instance, a kilogramme of cashew nut yields about 6000 calories compared to 3600 calories from cereals, 
1800 calories from meat and 650 calories from fresh citrus fruit [37]. Similarly, Nayar [1] observed that cashew nuts have only $1 \%$ of soluble sugar; consequently, the consumer of cashew is privileged to get a sweet taste without having to worry about excess calorie intake from sugary substances.

\subsection{Principal component analysis (PCA)}

PCA was employed to reveal possible spatial variations in the metal constituents of cashew nut according to the study areas (Fig. 1). The analysis was based on correlation matrix; the accepted significance level of $<0.05$ was selected and the probability associated with the Bartlett's test is $<0.001$. The Kaiser Criterion was employed in choosing the number of components, and only factors with eigenvalues greater than 1 were retained [19]. In addition, loadings $<0.5$ are considered poor while loadings $>0.9$ are typically regarded as excellent.

Table 4 shows the factor loadings, number of significant factors, and total variance (\%) that were explained by using Varimax with Kaiser normalized rotation method. PCA data revealed that a 2-component solution (varifactors) would be sufficient to explain $75.81 \%$ of the total variance (Table 4 and Fig. 1). The factor loadings (Table 4) demonstrated that the first varifactor (V1) explained $43.43 \%$ of the total variance and loaded primarily by positively correlated $\mathrm{Ca}, \mathrm{Cu}, \mathrm{K}, \mathrm{Mg}, \mathrm{Mn}$ and $\mathrm{Ni}$ (range of loadings: $0.714-0.943$ ). The second varifactor (V2) explained $32.38 \%$ of the overall variance and was loaded heavily on the positively correlated variables describing $\mathrm{Fe}, \mathrm{Na}$ and $\mathrm{Zn}$ (loadings ranging from $0.801-0.871$ ). The interrelationships among the metals in the two varifactor spaces are shown as PCA plots (Fig. 1). Careful observation of Figure 1 shows that elements clustered in groups. For example, the cluster Fe-Na-Zn is linked with the first varifactor, while Ca-Ni$\mathrm{Mg}-\mathrm{Mn}$ is linked with the second varifactor. Metals in each of the two varifactors showed very strong positive correlation suggesting the metals could be of natural sources only.

Table 4. Factors loading after Varimax normalized rotation

\begin{tabular}{lll}
\hline Element & $\mathrm{V} 1$ & $\mathrm{~V} 2$ \\
\hline $\mathrm{Ca}$ & $\mathbf{0 . 7 4 3}$ & 0.426 \\
$\mathrm{Cu}$ & $\mathbf{0 . 8 8 2}$ & 0.270 \\
$\mathrm{Fe}$ & 0.230 & $\mathbf{0 . 8 7 1}$ \\
$\mathrm{K}$ & $\mathbf{0 . 9 4 3}$ & -0.054 \\
$\mathrm{Mg}$ & $\mathbf{0 . 6 2 3}$ & 0.473 \\
$\mathrm{Mn}$ & $\mathbf{0 . 8 0 1}$ & 0.421 \\
$\mathrm{Na}$ & 0.222 & $\mathbf{0 . 8 0 1}$ \\
$\mathrm{Ni}$ & $\mathbf{0 . 7 1 4}$ & 0.390 \\
$\mathrm{Zn}$ & 0.221 & $\mathbf{0 . 8 4 0}$ \\
Variability (\%) & 43.431 & 32.383 \\
Cumulative (\%) & 43.431 & 75.814 \\
\hline
\end{tabular}

Note: Values in bold correspond for each variable to the factor for which the squared cosine is the largest

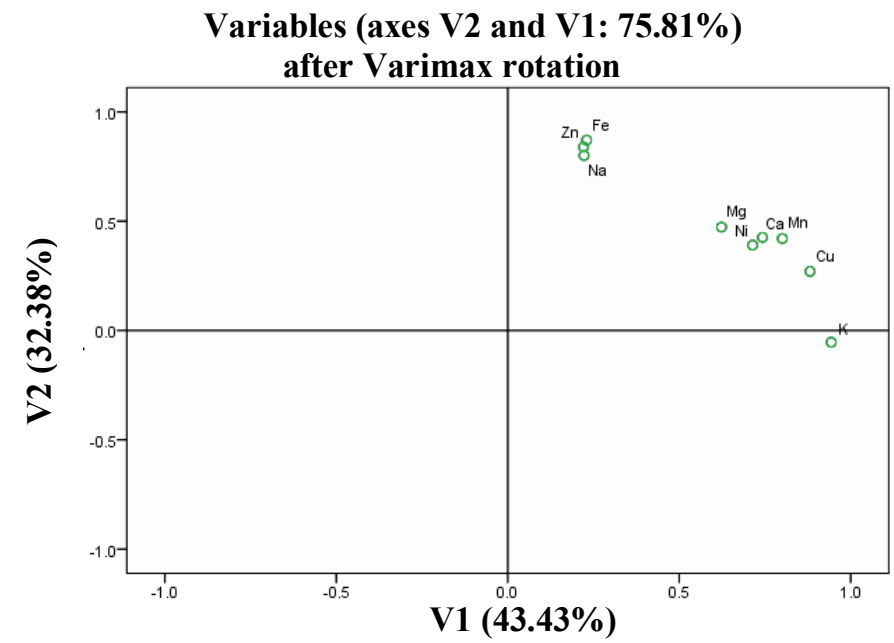

Figure 1. Plots of loadings (Varimax rotation) based on the concentration of elements in cashew nuts in space of first and second varifactors 


\section{Conclusion}

The results of this study provide detailed information on some micro- and macro-element contents of roasted cashew nuts on sale in southeastern Nigeria and the benefits of regular consumption of roasted cashew nuts, and contribute to the existing data. The results shows roasted cashew nut from southeastern Nigeria to be very rich in $\mathrm{K}, \mathrm{Mg}, \mathrm{Ca}$, and $\mathrm{Na}$ ranging from $5400-7100,2700-3100,290-430$ and $2300-3000 \mathrm{mg} / \mathrm{kg}$ respectively, with undetectable levels of $\mathrm{Cd}$ and $\mathrm{Pb}$. Evaluations of metals intake from the consumption of cashew nuts have shown that occasional or relatively frequent eating of cashew nuts does not pose any toxicological health concern, rather it will constitute a good source of nutrients including $\mathrm{Fe}, \mathrm{Cu}$ and $\mathrm{Zn}$. This study identified slight variations in the metals content of roasted cashew nuts from different towns in southeastern Nigeria. This could result from the variation in the mineral compositions of soils in which the cashew trees grew or from variations in the cashew nuts preparation and roasting methods. The result of PCA analysis showed interrelationships among the metals and suggest that metals contained in cashew nuts could be of natural sources.

\section{Acknowledgment}

Acknowledged is the systematic assistance of Professor J. Falandysz of the Research Group of Environmental Chemistry, Ecotoxicology \& Food Toxicology, Institute of Environmental Sciences \& Public Health, University of Gdansk, Poland.

\section{References}

[1] K.G. Nayar, Cashew: A versatile nut for health. In "Proceedings of International Cashew and Coconut Conference. Trees for LifeThe Key to Development" (C.T. Topper, P.D.S. Caligari, A.K. Kulaya, S.H. Shomari, L.H. Kasuga, P.A.L. Masawe, and A.A. Mpunami, Eds.), (BioHybrids International Ltd, Reading, UK, 1998) 195-199.

[2] S.H. Azam-Ali and E. Judge, (Small-scale cashew nut processing, ( http://www.fao.org/ag/ags/agsi/Cashew/Cashew.htm, 2001)

[3] J.G. Vaughan and C. Geissler, The new oxford book of food plants. (New York: Oxford University Press, 1997)

[4] R.P. Santos, A.A.X. Santiago, C.A.A. Gadelha, J.B. Cajazeiras, B.S. Cavada, J.L. Martins, T.M. Oliveira, G.A. Bezerra, R.P. Santos and V.N. Freire, Production and characterization of the cashew (Anacardium occidentale L.) peduncle bagasse ashes. Journal of Food Engineering , 79, 2007, 1432-1437.

[5] J.G. Ohler, Cashew. (Koninklijk Instituut Voo de Tropen: Amsterdam, Netherlands, 1979).

[6] T.M. Venkataramah, Cashew nut production and processing - Nigeria agronomic aspect of cashew nut production. (Unpublished paper submitted to CRIN, 1976)

[7] E.U. Asogwa, L.A. Hammed, T.C.N. Ndubuaku, Integrated production and protection practices of cashew (Anacardium occidentale) in Nigeria, African Journal of Biotechnology 7(25), 2008, 4868-4873.

[8] FAO, Major food and agricultural commodities and producers - countries by commodity". (http://faostat.fao.org/site/567/DesktopDefault.aspx?PageID=567\#ancor. Retrieved 2012-08-18, 2011).

[9] O.M. Aliyu and L.A. Hammed, Nigerian cashew economy: A review of nut production sector. Paper presented at the International Academy of African Buisiness and Development (IAABD) Conference. University of Florida, Gainesville, USA, 2008.

[10] C. Cabrera, M.L. Lorenzo and C.M. Lopez, Lead and cadmium contamination in dairy products and its repercussion on dietary intake. Journal of Agriculture and Food Chemistry 43, 1995, 1605-1609.

[11] I.C. Nnorom, G. Jarzynska, J. Falandysz, M. Drewnowska, I. Okoye, C.G. Oji-Nnorom, Occurrence and accumulation of mercury in two species of wild grown Pleurotus mushrooms from Southeastern Nigeria. Ecotoxicology and Environmental Safety 84, 2012, 78-83.

[12] I.C. Nnorom, G. Jarzyńska, M. Drewnowska, A. Dryżałowska, A. Kojta, S. Pankavec, J. Falandysz, Trace elements in sclerotium of Pleurotus tuber-regium (Ósū) mushroom - dietary intake and risk in Southeastern Nigeria. Journal of Food Composition and Analysis 29, 2013, 73-81.

[13] I.C. Nnorom, Lead and copper contents of the sclerotium of the mushroom Pleurotus tuber-regium (Osu): assessment of contribution to dietary intake in southeastern Nigeria, Toxicological \& Environmental Chemistry 93(7), 2011, 1359-1367.

[14] I.C. Nnorom, O. Osibanjo and K. Ogugua, Trace heavy metal levels of some bouillon cubes, and food condiments readily consumed in Nigeria. Pakistan Journal of Nutrition 6 (2), 2007, 122-127.

[15] I. Rodushkin,E. Engstrom, D. Sorlin and D. Baxter, Levels of inorganic constituents in raw nuts and seeds on the Swedish market, Science of the Total Environment 392, 2008, 290-304.

[16] S.K. Sathe, K.W.C. SzeTao, W.J. Wolf and B.R. Hamaker, Biochemical characterization and in vitro digestibility of the major globulin in cashew nut (Anacardium occidentale), Journal of Agricultural and Food Chemistry 45, 1997, 2854-2860.

[17] A.N. Nascimento, J. Naozuka and P.V. Oliveira, In vitro evaluation of $\mathrm{Cu}$ and Fe bioavailability in cashew nuts by off-line coupled SEC-UV and SIMAAS. Microchemical Journal 96, 2010, 58-63.

[18] V.R. Preedy, R.R. Watson and B.P. Vinood, Nuts and seeds in health and disease prevention, (Academic Press of Elsevier, 32 Jameston Road London NW1 7BY UK, 2011).

[19] J.E. Jackson, A User Guide to Principal Components. (Wiley, New York, 1991)

[20] FDA, Dietary reference intakes for vitamin a, vitamin $k$, arsenic, boron, chromium, copper, iodine, iron, manganese, molybdenum, nickel, silicon, vanadium, and zinc. Report of the panel on micronutrients (National academy press, Washington, DC, Food and Drug Administration. Dietary supplements. Center for food safety and applied nutrition, 2001).

[21] FAO/WHO, Human vitamin and mineral requirements. (Report of a Joint FAO/WHO expert consultation Bangkok, Thailand, 2002)

[22] US Department of Agriculture (USDA), Nutrition and your health: dietary guidelines for Americans. 4th ed., (US Dept of Agriculture: Home and Garden Bulletin, Washington, DC, 1995).

[23] IOM (Institute of Medicine), Dietary reference intakes for vitamin a, vitamin $k$, arsenic, boron, chromium, copper, iodine, iron, manganese, molybdenum, nickel, silicon, vanadium and zinc. (Washington DC: National Academy Press, 2001).

[24] J. Naozuka, E.V. Carvalho, A.N. Nascimento and P.V. Oliveira, Elemental analysis of nuts and seeds by axially viewed ICP OES, Food Chemistry 124 (4), 2011, 1667-1672. 
[25] D. Desideria, M.A. Melia, C. Cantaluppib, F. Ceccottob,C. Rosellia and L. Feduzi, Essential and toxic elements in meat of wild and bred animals, Toxicological \& Environmental Chemistry 94 (10): 1995-2005

[26] A.Mir-Marqués, M.L. Cervera ML and Guardia M. (2012). A preliminary approach to mineral intake in the Spanish diet established from analysis of the composition of university canteen menus. Journal of Food composition and analysis 27, $2012,160-168$.

[27] J.W. Spears, E.E. Hatfield, R.M. Forbes and S.E. Koenig, Studies on the role of nickel in the ruminant, Journal of Nutrition 108, 1978, 313-320.

[28] F. Zhu, W. Fan, X. Wang, L. Qub and S. Yao. Health risk assessment of eight heavy metals in nine varieties of edible vegetable oils consumed in China. Food and Chemical Toxicology 49, 2011, 3081-3085

[29] D. Demirezen and K. Uruc, Comparative study of trace elements in certain fish, meat and meat products. Meat Science 74, 2006, $255-60$.

[30] A. Ikem and N.O. Egiebor, Assessment of trace elements in canned fishes (mackerel, tuna, salmon, sardines and herrings) marketed in Georgia and Alabama (United States of America). Journal of Food Composition and Analysis 18, $2054,771-787$.

[31] S. Kanumakala, A. Boneh and M. Zacharin, Pamidronate treatment improves bone mineral density in children with Menkes disease. Journal of Inherited Metabolic Disease 25, 2002, 391-398.

[32] W. Ashraf and A.A Mian, Levels of selected heavy metals in black tea varieties consumed in Saudi Arabia. Bulletin of Environment Contamination and Toxicology 81, 2008, 101-104.

[33] K. Schümann, T. Ettle, B. Szegner, B. Elsenhans and N.W. Solomons, On risks and benefits of iron supplementation recommendations for iron intake revisited. Journal of Trace Elements in Medicine and Biology 21, 2007, $147-168$.

[34] Anderson J, Young L, Long, E and Prior, S. Sodium in the Diet, (Colorado State University Extension. http://www.ext.colostate.edu/pubs/foodnut/09354.html, 2012)

[35] Food and nutrition board, Dietary reference intakes for calcium, phosphorus, magnesium, vitamin D, and fluoride. (Washington DC: National Academy press, 1999)

[36] B.K. Nandi, Cashew nut nutritional aspects. In: Integrated Production Practices of Cashew in Asia. Edited by M.K. Papademetriou and E.M. Herath.( FAO/UN. File://A:IFAO Document Repositoryfiles $\backslash$ AC45/EOB.HT M, 1998) 8.

[37] M.C. Nambiar, B. Rao, E.V.V. Thankamma, P.K. Pillai, Cashew. In: Bose TK, S.K. Mitra. (Eds) Fruits: Tropical and Subtropical, (Naya Prakash, Calculta, 1990) 386-419.

Table 1S. Correlation matrix of elements in samples from Ubakala and Omoba

\begin{tabular}{|c|c|c|c|c|c|c|c|c|c|c|c|}
\hline & & $\mathrm{Ca}$ & $\mathrm{Na}$ & $\mathrm{K}$ & $\mathrm{Mg}$ & $\mathrm{Ni}$ & $\mathrm{Cu}$ & $\mathrm{Fe}$ & $\mathrm{Mn}$ & $\mathrm{Zn}$ & \\
\hline & $\mathrm{Ca}$ & 1 & 0.861 & 0.852 & $0.923^{*}$ & $0.938^{*}$ & 0.144 & -0.329 & -0.003 & 0.322 & $\mathrm{Ca}$ \\
\hline & $\mathrm{Na}$ & 0.708 & 1 & 0.755 & $0.986^{* *}$ & $0.946^{*}$ & 0.061 & -0.172 & -0.415 & 0.149 & $\mathrm{Na}$ \\
\hline & $\mathrm{K}$ & $0.982^{* *}$ & 0.618 & 1 & 0.846 & 0.780 & -0.071 & -0.369 & -0.197 & 0.599 & $\mathrm{~K}$ \\
\hline 포 & $\mathrm{Mg}$ & 0.842 & $0.973^{* *}$ & 0.761 & 1 & $0.964^{* *}$ & 0.048 & -0.245 & -0.339 & 0.251 & $\mathrm{Mg}$ \\
\hline$\overline{\underline{T}}$ & $\mathrm{Ni}$ & $0.921^{*}$ & $0.895^{*}$ & $0.894^{*}$ & $0.949^{*}$ & 1 & -0.067 & -0.425 & -0.308 & 0.061 & $\mathrm{Ni} \stackrel{\circ}{g}$ \\
\hline อี & $\mathrm{Cu}$ & $0.976^{* *}$ & 0.656 & $0.996^{* *}$ & 0.783 & $0.920^{*}$ & 1 & 0.814 & 0.663 & 0.438 & $\mathrm{Cu} \tilde{\sigma}$ \\
\hline 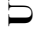 & $\mathrm{Fe}$ & $0.941^{*}$ & 0.863 & 0.870 & $0.939^{*}$ & $0.938^{*}$ & 0.878 & 1 & 0.326 & 0.301 & $\mathrm{Fe}$ \\
\hline & $\mathrm{Mn}$ & $0.960^{* *}$ & 0.875 & $0.916^{*}$ & $0.953^{*}$ & $0.985^{* *}$ & $0.930^{*}$ & $0.980^{* *}$ & 1 & 0.329 & $\mathrm{Mn}$ \\
\hline & $\mathrm{Zn}$ & $0.881^{*}$ & $0.956^{*}$ & 0.820 & $0.992^{* *}$ & $0.981^{* *}$ & 0.845 & $0.951^{*}$ & $0.977^{* *}$ & 1 & $\mathrm{Zn}$ \\
\hline
\end{tabular}

**. Correlation is significant at the 0.01 level (2-tailed).

*. Correlation is significant at the 0.05 level (2-tailed).

Table 2S. Correlation matrix of elements in samples from Ntigha and Uturu

\begin{tabular}{|c|c|c|c|c|c|c|c|c|c|c|c|}
\hline & & $\mathrm{Ca}$ & $\mathrm{Na}$ & $\mathrm{K}$ & $\mathrm{Mg}$ & $\mathrm{Ni}$ & $\mathrm{Cu}$ & $\mathrm{Fe}$ & $\mathrm{Mn}$ & $\mathrm{Zn}$ & \\
\hline & $\mathrm{Ca}$ & 1 & $0.907^{*}$ & $0.963^{*}$ & $0.912^{*}$ & 0.781 & $0.977^{* *}$ & $0.987^{* *}$ & $0.930^{*}$ & $0.987^{* *}$ & $\mathrm{Ca}$ \\
\hline & $\mathrm{Na}$ & $0.968^{* *}$ & 1 & $0.952^{*}$ & $0.983^{* *}$ & 0.857 & $0.945^{*}$ & $0.944^{* *}$ & $0.988^{* *}$ & $0.894^{*}$ & $\mathrm{Na}$ \\
\hline & $\mathrm{K}$ & $0.919^{*}$ & $0.949^{*}$ & 1 & $0.979^{* *}$ & 0.875 & $0.960^{* *}$ & $0.992^{* *}$ & $0.937^{*}$ & $0.930^{*}$ & $\mathrm{~K}=$ \\
\hline$\Xi$ & $\mathrm{Mg}$ & 0.800 & $0.887^{*}$ & 0.845 & 1 & $0.921^{*}$ & $0.948^{*}$ & $0.958^{*}$ & $0.960^{* *}$ & $0.891^{*}$ & $\mathrm{Mg}$ \\
\hline 50 & $\mathrm{Ni}$ & $0.951^{*}$ & $0.943^{*}$ & $0.986^{* *}$ & 0.831 & 1 & 0.868 & 0.828 & 0.837 & 0.790 & $\mathrm{Ni} \stackrel{5}{5}$ \\
\hline $\mathbf{Z}$ & $\mathrm{Cu}$ & $0.976^{* *}$ & $0.951^{*}$ & $0.963^{* *}$ & 0.835 & $0.992^{* *}$ & 1 & $0.972^{* *}$ & $0.969^{* *}$ & $0.987^{* *}$ & $\mathrm{Cu}$ \\
\hline & $\mathrm{Fe}$ & $0.941^{*}$ & $0.995^{* *}$ & $0.959^{* *}$ & $0.906^{*}$ & $0.939^{*}$ & $0.936^{*}$ & 1 & $0.944^{*}$ & $0.960^{* *}$ & $\mathrm{Fe}$ \\
\hline & $\mathrm{Mn}$ & 0.797 & $0.894^{*}$ & 0.823 & $0.994^{* *}$ & 0.803 & 0.810 & $0.912^{*}$ & 1 & $0.936^{*}$ & $\mathrm{Mn}$ \\
\hline & $\mathrm{Zn}$ & $0.933^{*}$ & $0.989^{* *}$ & $0.972^{* *}$ & $0.898^{*}$ & $0.949^{*}$ & $0.939^{*}$ & $0.998^{* *}$ & $0.899^{*}$ & 1 & $\mathrm{Zn}$ \\
\hline
\end{tabular}

**. Correlation is significant at the 0.01 level (2-tailed).

*. Correlation is significant at the 0.05 level (2-tailed). 
Table 3S. Correlation matrix of elements in samples from Uzoakoli and Obehie

\begin{tabular}{|c|c|c|c|c|c|c|c|c|c|c|}
\hline & $\mathrm{Ca}$ & $\mathrm{Na}$ & K & $\mathrm{Mg}$ & $\mathrm{Ni}$ & $\mathrm{Cu}$ & $\mathrm{Fe}$ & $\mathrm{Mn}$ & $\mathrm{Zn}$ & \\
\hline $\mathrm{Ca}$ & 1 & $0.973^{*}$ & $0.987^{* * \pi}$ & $0.985^{* *}$ & $0.992^{* *}$ & $0.992^{*}$ & $0.962^{* *}$ & $0.958^{*}$ & $0.994^{* 7}$ & $\mathrm{Ca}$ \\
\hline $\mathrm{Na}$ & $0.890^{*}$ & 1 & $0.989^{* *}$ & $0.930^{*}$ & $0.970^{* *}$ & 0.811 & $0.888^{*}$ & $0.880^{*}$ & $0.952^{*}$ & $\mathrm{Na}$ \\
\hline K & 0.828 & 0.860 & 1 & $0.955^{*}$ & $0.978^{* *}$ & 0.860 & $0.913^{*}$ & $0.901^{*}$ & $0.982^{* *}$ & $\mathrm{~K}$ \\
\hline$\div \mathrm{Mg}$ & $0.958^{*}$ & $0.926^{*}$ & 0.804 & 1 & $0.959^{* *}$ & $0.942^{*}$ & $0.956^{*}$ & $0.956^{* *}$ & $0.984^{* *}$ & $\mathrm{Mg}$ 。 \\
\hline$\frac{N}{\pi} \mathrm{Ni}$ & $0.937^{*}$ & $0.933^{*}$ & $0.955^{*}$ & $0.944^{*}$ & 1 & $0.920^{*}$ & $0.971^{* *}$ & $0.960^{* *}$ & $0.982^{* *}$ & $\mathrm{Ni}$ \\
\hline $\mathrm{Cu}$ & $0.964^{* *}$ & $0.938^{*}$ & $0.890^{*}$ & $0.987^{* *}$ & $0.985^{* *}$ & 1 & $0.982^{* *}$ & $0.980^{* *}$ & $0.936^{*}$ & $\mathrm{Cu} \stackrel{0}{-}$ \\
\hline $\mathrm{Fe}$ & $0.894^{*}$ & $0.899^{*}$ & $0.981^{* *}$ & $0.898^{*}$ & $0.992^{* *}$ & $0.957^{*}$ & 1 & $0.995^{* *}$ & $0.959^{* *}$ & $\mathrm{Fe}$ \\
\hline $\mathrm{Mn}$ & $0.987^{* *}$ & 0.849 & 0.867 & $0.940^{*}$ & $0.952^{*}$ & $0.963^{* *}$ & $0.925^{*}$ & 1 & $0.950^{*}$ & $\mathrm{Mn}$ \\
\hline $\mathrm{Zn}$ & $0.913^{*}$ & $0.982^{* *}$ & $0.938^{*}$ & $0.918^{*}$ & $0.974^{* *}$ & $0.956^{*}$ & $0.958^{*}$ & $0.899^{*}$ & 1 & $\mathrm{Zn}$ \\
\hline
\end{tabular}

**. Correlation is significant at the 0.01 level (2-tailed).

*. Correlation is significant at the 0.05 level (2-tailed). 